TEME, г. XLV, бр. 1, јануар - март 2021, стр. 145-164

Прегледни рад https://doi.org/10.22190/TEME200131009A

Примљено: 31. 1. 2020.

UDK 327(510:497-15)

Ревидирана верзија: 27. 1. 2021.

Одобрено за штампу: 26. 2. 2021.

\title{
THE SINO-WESTERN BALKANS RELATIONS WITHIN "BELT AND ROAD" INITIATIVE AMIDST THE WORLD'S GRAPPLING WITH THE RISE OF CHINA
}

\author{
Sanja Arežina*
}

Government of the Republic of Serbia, Belgrade, Serbia

\begin{abstract}
The Sino-Western Balkans cooperation has advanced significantly since the Great Recession and the Eurozone crisis. Relations were developed at the bilateral and multilateral levels, within the "One Belt, One Road" Initiative (Belt and Road Initiative BRI) which was promoted in 2013 and which included the previously established Mechanism of Cooperation between China and the Central and Eastern European Countries ("17+1" Mechanism). Although the Chinese President Xi Jinping called BRI a "project of the century" in 2017, new international circumstances caused by the intensified the Sino-US rivalry and the COVID-19 pandemic made the Chinese leadership reconsider activities and funding abroad, and adjust the new 14th Five-Year Plan with changes that have taken place in the past five years. They decided that China will focus on "dual circulation" in the coming period, i.e. to reduce the numerous activities and investments (and loans) within the BRI, and to redirect funds to investing in domestic capacities. In this article, the author discusses the China-Western Balkans relations from 1949 until 2013 when the BRI implementation started, the factors influencing China's cooperation with the Western Balkans and analyzes the progress of cooperation after the start of the BRI implementation compared to the previous period. In order to prove the basic hypothesis, that Sino-Western Balkan cooperation within the "Belt and Road" Initiative will continue to develop in a positive direction, despite the influence of negative factors, and above all due to the good results achieved within the "Belt and Road" Initiative in 2013, the author uses the structural-functional analysis, comparative analysis, induction and deduction.
\end{abstract}

Key words: China, Western Balkans, "Belt and Road" Initiative, European Union, United States.

\footnotetext{
* Аутор за кореспонденцију: Сања Арежина, Влада Републике Србије, Немањина 22-26, 11000 Београд, Србија, sanja_arezina@yahoo.com
} 


\section{ОДНОСИ КИНЕ И ЗАПАДНОГ БАЛКАНА У ОКВИРУ „ПОЈАС И ПУТ" ИНИЦИЈАТИВЕ УСРЕД СВЕТСКЕ БОРБЕ СА РАСТОМ КИНЕ}

\section{Апстракт}

Сарадња између Кине и Западног Балкана значајно је напредовала након Велике рецесије и кризе Еврозоне. Односи су развијани на билатералном и мултилатералном нивоу, у оквиру „Један појас, један пут” иницијативе (иницијатива „Појас и пут” - БРИ), која је промовисана 2013. године и која је обухватила претходноосновани Механизам сарадње Кине и земаља Централне и Источне Европе (Механизам „17 + 1”). Иако је кинески председник Си Ђинпинг 2017. године БРИ назвао „пројектом века", нове међународне околности, изазване појачаним ривалством између САД и Кине, као и пандемијом вируса корона SARS-CoV-2, учиниле су да кинеско руководство преиспита активности и финансирања у иностранству, а нови, 14. по реду, Петогодишњи план усклади са променама које су се десиле у претходних пет година. Одлучено је да у наредном периоду Кина фокус стави на „двоструку циркулацију", односно да смањи број активности и инвестиција (и зајмова) у оквиру БРИ и да средства преусмери на инвестирање у домаће капацитете. Ауторка у чланку разматра односе Кине и Западног Балкана од 1949. године до 2013. године, када је започела примена БРИ, факторе који утичу на сарадњу Кине са државама Западног Балкана и анализира напредак сарадње након почетка примене БРИ у односу на претходни период. Да би доказала основну хипотезу да ће се кинеско-западнобалканска сарадња у оквиру иницијативе „Појас и пут” и даље развијати у позитивном смеру, упркос утицају негативних фактора, а пре свега због добрих резултата постигнутих у оквиру иницијативе „Појас и пут” 2013. године, ауторка користи структурно-функционалну анализу, компаративну анализу, индукцију и дедукцију.

Кључне речи: Кина, Западни Балкан, иницијатива „Појас и пут”, Европска унија, Сједињене Америчке Државе.

\section{INTRODUCTION}

At the beginning of the $21^{\text {st }}$ century, when China reached a high rate of foreign exchange reserves, and especially after the Global Financial Crisis of 2008, when most of the state economies were facing its effects in the lobby or at the very epicenter of the recession, a growing number of European national and non-state actors began to perceive Beijing as a potential partner for cooperation (Song, 2012). While helping the EU countries during the crisis, China has prevented the weakening of the EU as an important actor in safeguarding the multipolar world and as its export market, a source of new technology and equipment and one of the largest sources of foreign investment (COASI, 2018). At the same time, it has reduced the possibility to suffer losses itself with the ambition to open up the European market for Chinese investments and wanting to influence European officials to ease arms trade restrictions and sensitive high-tech products that are necessary for the new national economic model and 
achieving the "Chinese dream" by 2049 (Zhongguo Meng) (Gong, 2013). ${ }^{1}$ Through such behavior, China wanted to demonstrate that it represents a "responsible great power" (Fuzeren de Daguo) in solving global issues (Arežina, 2018, p. 147).

Simultaneously with the more intensive development of Sino-EU relations, China improved relations with the region for which the European Union has devised a special political name - the Western Balkans, which consists of five non-EU countries: Serbia, Montenegro, Bosnia and Herzegovina, North Macedonia and Albania. It did so bilaterally and multilaterally through the Mechanism of Cooperation between China and the Central and Eastern European Countries - CEEC's (the so-called "16+1" Mechanism or "17+1" Mechanism) which was established in 2012. Thanks to this, the exchange of high-level visits and trade cooperation has been enhanced, the amount of Chinese foreign direct investment has increased, and numerous partnership agreements have been signed.

Progress in cooperation has continued following the promotion of "One Belt, One Road" Initiative ("Belt and Road" initiative - BRI, Yidai Yilu) by Chinese President Xi Jinping in 2013, which aims to link the two economically developed parts of Eurasia (Western Europe and the eastern part of China) by land and sea, and bringing benefits to all states along this road. This initiative included sporadic smaller projects implemented in the past by China along the ancient Silk Road route, as well as existing mechanisms for cooperation with countries along the road, including the "17+1" Mechanism (Arežina 2018, p. 254).

Although, in 2017, President Xi Jinping called the "Belt and Road" Initiative "a project of the century" in which China will invest 1 trillion dollars, due to the growth of the negative narrative about China (because of the strengthening of the Sino-US rivalry) and China's inability to collect borrowed money due to the crisis caused by the COVID-19 pandemic, at the meeting of the Politburo held in May 2020 the Chinese leadership decided that China will focus on internal circulation in the next five years. In this regard, the new 14th Five-Year Plan (2021-2025) relies more on "dual circulation" according to which China will continue to invest abroad, but the significant amount of money invested in BRI so far will be redirected to the domestic market (Kynge, Wheatley, 2020). This means that Chinese investments and loans within "Belt and Road" initiative will decrease in the coming period, and China will continue to invest and lend only to countries with which it has extremely good political relations and which are able to repay their debts. Therefore, the basic hypothesis of this research is that the Sino-Western Balkans cooperation within

\footnotetext{
${ }^{1}$ In November 2012, at the Third Plenum of $18^{\text {th }}$ Congress, President Xi Jinping mentioned the vision of the "Chinese Dream", which he subsequently clarified as the accomplishment of a large number of internal reforms agreed in the Program of 60-point.
} 
the "Belt and Road" Initiative will continue to develop in a positive direction despite the influence of negative factors, primarily due to win-win results achieved after the promotion of the "Belt and Road" Initiative in 2013.

In the past period, researches on the relationship between China and the Western Balkans countries have focused mainly on the positive and negative aspects of cooperation. This research focuses on the comparative analysis of Sino-Western Balkans cooperation before and after the promotion of the "Belt and Road" Initiative, and the factors that influence the dynamics of their relationship. In the research, the author answers the following questions: What were the Sino-Western Balkans relations before the start of the implementation BRI? What were the Sino-Western Balkans relations after the start of the implementation of BRI? What factors affect the dynamics of the BRI implementation in Western Balkans? What is the future of this cooperation? To be able to prove the basic hypothesis, the author uses the structuralfunctionalist analysis, comparative analysis, induction, and deduction. The research will use relevant academic and policy documentation, official statements and news from the US, Chinese, European and other international media. Also, for the sake of authenticity, the research was enriched by formal and informal interviews and conversations the author had with the US, the European and the Chinese officials, analysts, researchers, journalists and businessmen who were directly involved in the various aspects of SinoEuropean relations.

The article has five parts. In the introduction, the author gives the context for the research, explains the crux of the problem and sets out the hypotheses. In the second part, the author explains the history of SinoWestern Balkans relations before the promotion of the "Belt and Road" Initiative. In the third part, the author outlines the factors that affect cooperation between China and the Western Balkan countries within the "Belt and Road" Initiative. The fourth part provides the comparative analysis of Sino-Western Balkans cooperation before and after the start of the BRI implementation. The concluding remarks will summarize the research and the conclusions reached, after which the author draws a conclusion on BRI's role in the ongoing development of Sino-Western Balkans cooperation, provides a projection of the direction of the future Sino-Western Balkans relations and makes recommendations for further cooperation within the "Belt and Road" Initiative.

THE HISTORY OF SINO-WESTERN BALKANS RELATIONS BEFORE THE "BELT AND ROAD" INITIATIVE IMPLEMENTATION

In the previous period, there was no Chinese official document with an explicitly defined attitude towards the Western Balkans as a separate region at the European continent. However, China has always seen 
this region as an integral part of Southeast Europe, and then, since 2012, after the formation of the "17+1" Mechanism this region was placed within the framework of the wider Central and Eastern European region (Mitrović, 2011, p. 265).

Bilateral relations between China and Western Balkan countries began to develop in 1949, after Mao Zedong proclaimed the founding of the PR China at Tiananmen Square. China's diplomatic relations with Yugoslavia have had their ups and downs, while diplomatic relations with Albania were at a very high level until the late 1970s. However, shortly after the Yugoslav President Josip Broz Tito's visit to Beijing in 1977, party relations between China and Albania were severed, and those between China and Yugoslavia established. During the 1980s, a large number of high-level political delegations were exchanged between China and Yugoslavia, as well as experts who were very important for the process of "reform and opening up" China (Arežina, 2018, p. 223).

After the end of the Cold War and the fall of the communist regimes in Eastern Europe, the Western Balkan countries began to pursue a predominantly Western-oriented foreign policy, promoting the EuroAtlantic integration as one of the most important foreign policy goals. During the Eurocrisis in 2009, the Western Balkan countries very quickly adopted the "Opening to the East" strategy, actively absorbing investments that come from China, in order to fill the existing vacuum created by the lack of fresh money in the Eurozone countries and continue their economic growth (Liu, 2013, p. 3). In this sense, they seek to strengthen bilateral relations with China (political, economic, cultural, etc.), and also multilaterally within the "17+1" Mechanism established by China in 2012. So far, 9 economic and trade forums and 8 political summits of the prime ministers of Central and Eastern European countries and China have been held. ${ }^{2}$ In the course of time, numerous institutional mechanisms for cooperation in various fields were developed between China and the Western Balkans countries within this Mechanism, in which cooperation progressed in all segments: strengthening bilateral trade, two-way investment, infrastructure cooperation, deepening fiscal and financial cooperation and exchanging experts in various fields (Wen, 2011).

In 2012, as support to the Mechanism, Beijing established an Investment Fund with the initial capitalization of $10+3$ billion dollars, which was spent to revitalize and build infrastructure in the CEE region, as well as to support Chinese companies for active participation in publicprivate partnerships and the privatization processes in this region. After

2 The summits are held in Budapest (2011), in Warsaw (2012), in Bucharest (2013), in Belgrade (2014), in Suzhou (2015), in Riga (2016), in Budapest (2016), in Sofia (2018), in Dubrovnik (2019). Due to the COVID-19 pandemic, no summit was held during 2020. 
the Chinese President Xi Jinping promoted the "Belt and Road" Initiative in 2013, which represents a transcontinental long-term policy and investment program of China which aims to connect Asia with Africa and Europe via land and maritime networks in order to improve regional integration, increasing trade and stimulating economic growth, the "17+1" Mechanism has become an integral part of it, along with all the projects previously implemented in this region (including Western Balkans). Over the years, the cooperation has developed in various areas within BRI, from people to people exchanges to infrastructure, energy, social and cultural projects (Arežina, 2018, p. 254).

\section{THE FACTORS THAT AFFECT THE SINO-WESTERN BALKANS COOPERATION WITHIN THE "BELT AND ROAD" INITIATIVE}

China-Western Balkans relations are influenced by a number of different factors, most notably the importance of China in the $21^{\text {st }}$ century as an international contributor to solving global problems. As a permanent member of the UN Security Council, a nuclear power, the largest holder of foreign exchange reserves and a UN peacekeeping contributor, its voice has great weight internationally. Consequently, most countries tend to establish, preserve and strengthen good relations with Beijing, which also applies to the Western Balkans region.

The second factor is the traditionally good relations of the Western Balkan countries with China. Namely, all the countries of this region, as part of the Eastern Bloc, recognized the PR China soon after the Soviet Union did, in 1949 (Liu, 2013, p. 3). However, at that time, although most of them were communist countries, only Albania had party relations with China in addition to diplomatic relations. In the late 1970s, China broke off party relations with Albania and established it with the SFR Yugoslavia, which during the period of "opening up" provided the greatest support for Chinese reforms. With the end of the Cold War, following the fall of communist regimes (and the breakup of the SFR Yugoslavia), the Western Balkan countries are beginning to pursue a foreign policy predominantly West oriented, promoting EU integration as one of their foreign policy goals. China is supporting them in this, having in mind, first and foremost, the need for partners in the decision-making process within their respective European policies.

The third significant factor affecting China's relations with the Western Balkan countries is the region's good geographical position and proximity to the EU market. Namely, because of its strong economic expansion over the past few decades, and especially after the Global Financial Crisis of 2008, China has made it possible to place surplus capital to markets around the world, as well as to the European market, thanks to the "Belt and Road" Initiative. In this regard, the Western Balkans region is a 
geographical link, within the maritime component of this project, between Greece, where the Chinese company COSCO has been involved in the operation of the Port of Piraeus since 2009, and Central and Western Europe. Thus, Chinese products arrive by sea from China to the Piraeus port, and then are transported further by road and railway (Corridor 10) through North Macedonia, Serbia and Hungary to Central and Western Europe.

In addition, the Western Balkans region is a form of preparatory ground on which Chinese companies gain experience in operating in accordance with the EU standards, but without the stronger EU competition or stronger EU regulatory pressure. This is especially significant after the failure of the Chinese company COVEC to build a highway between Berlin and Warsaw. It also corresponds to Chinese companies that these countries have direct and privileged access to the entire EU market, lower taxes, qualified low-income labor, and the ability to provide state guarantees in order to receive preferential loans, which EU member countries are unable to do (Arežina, 2020b, p. 8).

The fourth factor is the Western Balkan countries' need for fresh capital to fill the investment vacuum created by the weakening economic and financial capacity of most of the European countries during the Global Financial Crisis and the Eurozone Crisis. The lack of funding in developed European countries amid the Eurozone crisis is an important reason why countries in the region have turned to partnering with China in order to attract as much funding as possible. This factor is even more pronounced in the context of the Sino-US rivalry and the COVID-19 pandemic. Unlike EU member countries that have the ability to use Structural and Cohesion Funds, as well as different emergency and solidarity funds, the Western Balkan countries have the opportunity to get preferential loans no strings attached from Chinese banks for 10-20 years at 2-4\% interest rate and the 3 to 7 -year grace period.

The fifth important factor affecting China's relations with the Western Balkan countries is relations with the European Union. After the end of the Cold War and the fall of communist regimes in Eastern Europe, the Western Balkan countries began to pursue a predominantly Western-oriented foreign policy, promoting the Euro-Atlantic integration as one of the most important foreign policy goals. However, although these countries have been in the process of stabilization and association for almost two decades, none of them has yet become an EU member country. Montenegro and Serbia are candidates for membership that have opened majority of negotiation chapters. North Macedonia and Albania are also the EU candidate countries, but although they received the green light to open the accession negotiations in March 2020, the date for the start of the negotiations has not yet been set. Bosnia and Herzegovina has not yet become a candidate country (Arežina, 2020a, p. 4). Due to slow progress, the lack of clear and explicit promises that the expansion of EU will continue, as well as the less attractive vision of EU 
membership, in some of them, such as Serbia and Bosnia and Herzegovina, public opinion is mostly negative towards EU integration (Arežina, 2020a, p. 5). Therefore, these countries often do not harmonize their regulations with EU regulations (they sign interstate agreements without conducting public tenders, do not harmonize foreign policy decisions with EU decisions, etc.), which causes a feeling of insufficient commitment of these countries to the process of European integration.

On the other hand, Beijing wants to have good partnership relations with Brussels, primarily because they share the interest for a more balanced international order based on effective multilateralism. China and the EU are significant trading partners, with around 1.5 billion euros in daily trading, which is especially important because of the economic consequences of the COVID-19 pandemic. The European Union market is very important for exporting Chinese products and placing Chinese investment given the SinoUS rivalry that has existed since 2017, and vice versa. However, after the establishment of the "17+1" Mechanism in 2012, some statements by Brussels officials indicated that the EU was increasingly perceiving this mechanism as a "Trojan horse" and one more step in a series of Chinese attempts to enter the European Union through the back door and divide it into the East and the West. Therefore, CEE countries and especially EU candidate countries from the Western Balkans were advised not to "violate EU regulations" when concluding economic agreements with China, and a warning was issued regarding the use of preferential Chinese loans, due to the possibility of it being a "debt trap" (Arežina, 2018, p. 248; United State Senate, 2018).

In order to prevent animosity towards strengthening China's cooperation with the CEE and especially the Western Balkans, Chinese officials have always stated in their statements that the aim of this cooperation is to develop a regional approach based on equality and mutual respect and benefit, mutual development and effort, in order to advance relations between China and Europe. According to them, China's relationship with this region is not an attempt to implement the "conquer and rule" strategy, but to build one more Chinese "bridge to Europe", which, above all, should serve as a way to strengthen relations with the European Union (Xinhua, 2013). ${ }^{3}$ At the same time, officials from CEE countries stressed that their intention was not to form a bloc against the EU, but to act in accordance with EU regulative (Pavlićević, 2019, p. 464). Moreover, in practice, these countries are bigger rivals among themselves therefore wanting to attract Chinese investment more than wantingto provoke negative reactions from Brussels.

\footnotetext{
3 The example of this is the Chinese insistence that Greece remains within the Eurozone not to weaken EU's position in the global economy.
} 
The sixth significant factor, and perhaps the most significant impact to China's relations with the Western Balkan countries, is relations with the US. As the largest global power that guarantees security to many allies, the US are in a position to impose their foreign policy views and goals on other countries in the world. Unlike President Barack Obama's tenure, when China was a constructive partner ("Chimerica"), President Donald Trump's rise to power changed the existing perception of "China as a partner" to "China as a potential rival" (Ferguson, 2007). When the US began the "trade war" with China, the US Secretary of State, Mike Pompeo, gave the opportunity to the allies to show how willing they were to pursue the US interests around the world. Washington has called on Brussels to combat the unfair Chinese trade with a view to reducing the takeover of sensitive hi-tech technologies on the European continent. This led the European Union to start blocking the acquisition of certain security-sensitive companies by Chinese companies and seek to accelerate the introduction of protective measures in the European market that would restrict the entry of Chinese capital, especially in security-sensitive sectors (EU Screening Mechanism for Foreign Direct Investment, International Public Procurement Instrument, Improvement of Labor and Ecological Standards, etc.) (US Embassy of Georgia, 2017; Smith, 2018). In addition, Brussels went one step further and referred to China in March 2019 as a "systemic rival and economic competitor", which was reaffirmed again in October 2020. These Brussels' policies, as well as the restrictive measures introduced by the Chinese leadership in August 2017 to increase controls on the exit of capital from the country, have resulted in a reduction of Chinese investments in the European Union market from 37.3 billion euros in 2016 to 29.1 billion euros in $2017,17.3$ billion euros in 2018 , and 11.7 billion euros in 2019 (Hanemann, 2018; Rhodium Group, 2019). At the same time, when it comes to the Western Balkan countries, there is a tendency to increase the number of Chinese investments and start projects for which funds are obtained through Chinese banks as preferential loans.

The seventh significant factor is the COVID-19 pandemic. In August 2017, China introduced certain restrictions on the approval of funds for investments and loans to Chinese companies abroad. After that, the Sino-US rivalry, which has begun to spill over to Washington's allies, has further reduced opportunities for Chinese investment abroad. However, the most significant reduction of the Chinese investments and loans within BRI came due to the crisis caused by the COVID-19 pandemic in 2020. During this period, Chinese outbound investment was only 14.11 billion dollars (Ministry of Commerce of the PR China, 2020), while Chinese financial institutions approved only 4 billion dollars for outbound loans, which is a significantly smaller amount compared to the previous few years, especially to 75 billion dollars in 2016 (Kynge, Wheatley, 2020). Due to the inability to repay their debts, Chinese President Xi Jinping granted the relief of debts worth 2 billion 
dollars for the least developed countries, while debt refinancing was negotiated with 18 countries. Moreover, the crisis was also felt by some Chinese companies due to delays in the implementation of projects, supply chain disruptions and unplanned cost increases. Therefore, at the meeting of the Politburo in May 2020, a decision was made that China will focus on internal circulation in the next five years. In this regard, the new $14^{\text {th }}$ FiveYear Plan relies more on "dual circulation", according to which China will continue to invest abroad, but part of the money invested in BRI so far will be redirected to the domestic market (Kynge, Wheatley, 2020).

On the other hand, the Western Balkan economies are also burdened by the consequences of the pandemic. Their public debts are growing, as a result of which they will not be able to give state guarantees for taking preferential loans from Chinese financial institutions, but will have to finance projects through concessions or public-private partnerships. Also, the question is whether they will be able to finance the debts they have made so far towards their Chinese partners. For now, Serbia, Bosnia and Herzegovina and North Macedonia have a problem with the rise of public debt, but they still do not have problems with repaying debts to Chinese financial institutions. However, if the pandemic continues and the funds received from the $\mathrm{EU}$ are not enough to remedy the crisis caused by the pandemic, all governments will have to prioritize spending and support for households and businesses over the financing for BRI infrastructure projects. Montenegro and Albania have a high public debt because of tourism-dependent economy (over $80 \%$ of GDP), which is likely to result in seeking loans refinancing (Vukićević, 2020; Svetska Banka, 2020).

\section{COMPARATIVE ANALYSIS ON SINO-WESTERN BALKANS RELATIONS BEFORE 2013 AND AFTER THE PROMOTION OF THE "BELT AND ROAD" INITIATIVE}

In order to determine the effect of BRI on Sino-Western Balkans cooperation, it is necessary to make a comparative analysis of their cooperation in the period before the promotion of BRI and after 2013, when numerous initiatives in various areas began to be implemented within this initiative. The comparative analysis will cover five Western Balkan countries and the three most important areas of cooperation: political, economic and cultural cooperation. The intensity of cooperation will be measured by the number of realized projects in all three mentioned areas between China and the countries of this region in the period before the promotion of BRI and after 2013.

Serbia. In the period before 2013, Serbia signed the Strategic Partnership Agreement with China (2009), after which political relations progressed, especially regarding China's support to Serbia within the framework of international organizations concerning the membership of 
Kosovo*. ${ }^{4}$ In the first years after the Agreement two high-level visits followed, the first by the Chinese President Hu Jintao in 2009 and the second by the Chairman of the Standing Committee of National People's Congress Wu Bangguo in 2010. Many significant agreements and memoranda were signed in the period up to 2013, but only few have been implemented (Arežina, 2018, p. 239). Most of them were projects that were realized with the support of Chinese preferential loans (revitalization of TPP Kostolac, construction of the "Mihajlo Pupin" bridge over the Danube), while there were almost no direct investments. The Confucius Institute at the University of Belgrade was founded in 2006.

After the start of the BRI implementation, the cooperation between Serbia and China has progressed significantly. In addition to the summit meetings between the prime ministers of the two countries, visits by other high-ranking Chinese officials were constantly exchanged within the "17+1" Mechanism and the Belt and Road Forum for International Cooperation. In 2016, the Chinese President Xi Jinping visited Serbia, and on that occasion, a Comprehensive Strategic Partnership Agreement was signed. Belgrade hosted the Summit of the prime ministers and the Economic and Trade Forum under the "17+1" Mechanism in 2014 (Arežina, 2018, p. 190). Also, Serbia has been selected to be the seat of the Secretariat for Infrastructure Projects of this mechanism and a member of the Asian Infrastructure Investment Bank (AIIB).

Although Serbia, like most countries in the world, has a trade deficit with China, a number of significant veterinary and phytosanitary certificates have been harmonized. As a result, the largest Serbian companies can export their herbal and animal products to the Chinese market. Serbia has attracted a large number of Chinese investments, most notably the purchase of the Steel Mill "Smederevo", Coper Miner and Smelter "Bor", the construction of a tire factory in Zrenjanin, a car parts factory in Loznica, a car lights factory in Niš, the industrial park "Mihajlo Pupin", etc. In addition to Chinese investments, Serbia has received significant funding from the Exim Bank under preferential conditions for the implementation of numerous infrastructure projects. The most significant projects are the Reconstruction Project of the Hungarian-Serbian Railway, which should be part of the Thessaloniki-Budapest railway link, the Obrenovac-Ub highway, the Lajkovac-Ljig highway, the Surčin-Obrenovac highway, the Preljina-Pozega highway, the Pozega-Boljari highway and the construction of the bypass around Belgrade. So far, Serbia has withdrawn about 7 billion dollars from the CEEC Investment Fund (investments are over 2

\footnotetext{
4 According to the UN Security Council Resolution 1244 (1999) Kosovo and Metohija is a provisionally administered UN territory within the FR Yugoslavia and then within the successor states - the Republic of Serbia.
} 
billion dollars), with a tendency to reach 10 billion dollars after all the projects have been completed. Also, an additional Confucius Institute located in Novi Sad was opened in 2014. Serbia has opened a Cultural Center in Beijing, while the construction of the Chinese Culture Center in Belgrade is expected to be completed in 2021 at the same location where the former Embassy of the PR China was located before it was destroyed during the 1999 NATO bombing (Mondo, 2020). Chinese started to be taught in primary and secondary schools, as well as at the University of Belgrade.

Montenegro. In the period before 2013, Montenegro and China had relatively good co-operation (since diplomatic relations were established in 2006 after leaving the State Union of Serbia and Montenegro). However, there were no high-level visits, and apart from the 3 million dollars heavy truck assembly grant line, there were no significant Chinese investments and preferential loans during this period (Arežina, 2018, p. 235).

Relations began to develop more significantly only after the start of the BRI implementation and resulted in the signing of the Friendship and Cooperation Agreement in 2013 (Ministry of Foreign Affairs of the PR China, 2013). The High-level (Prime Minister) meetings have taken place mainly in the framework of the "17+1" Mechanism, as well as in other international events such as the Winter Olympics in Sochi in February 2014 and the Summer Youth Olympics in Nanjing in August 2014 (The Embassy of the PR China in Montenegro, 2016). There exists an inflow of Chinese direct investment to Montenegro through preferential loans. China's Exim Bank granted preferential loans for the purchase of four ships from Poly Technologies Group (Ekapija, 2009). Also, the loan was approved for the construction of a section of the road from Bar to Boljare (Smokovac-Mateševo), which sparked negative comments from 16 US senators who in August 2018 sent a letter to the US Secretary of State Mike Pompeo and the US Secretary of the Treasury Steven Mnuchin warning them of the problem in Montenegro and other countries (Pakistan, Sri Lanka and Djibouti) may have due to the unsustainable debts caused by Chinese loans (United States Senate 2018). Additionally, state electricity company "Elektroprivreda" signed a contract with Dongfang Electric Corp. on ecological reconstruction of TPP Pljevlje $\left(1^{\text {st }}\right.$ block). In this period, the Confucius Institute was established at the University of Montenegro in 2015, and Chinese started to be taught in primary and secondary schools.

Bosnia and Herzegovina. In the period before 2013, political cooperation was at a very low level, with no high-level visits, direct investment and preferential loans.

Only after the start of the BRI implementation did the cooperation begin to develop, largely driven by the "17+1" Mechanism, which is essentially the only forum for top official visits. However, in recent years Bosnia and Herzegovina has become an increasingly attractive invest- 
ment destination for the Chinese. There is very small amount of Chinese foreign direct investment, but there are more preferential loans granted by Chinese banks for various projects in Bosnia and Herzegovina, such as construction of TPP "Stanari", construction of TPP "Tuzla 7" and TPP "Banovići", a highway from Banja Luka to Mlinište, a hospital in Doboj, etc. It is important to note that the TPP "Stanari" is the first energy facility in Bosnia and Herzegovina that operates in accordance with the EU directives on environmental protection (2001/80/ EC) (Ačanski, 2013). Chinese started to be taught in primary and secondary schools, as well as at two Confucius Institutes located in Sarajevo and Banja Luka (Hanban News, 2015; Hanban News, 2018).

North Macedonia. In the period before 2013, North Macedonia and China maintained good relations and exchanged official visits, but good relations were interrupted due to the Macedonian recognition of Taiwan in 1999, after which China suspended diplomatic relations with Macedonia (Global Policy Forum, 1999). ${ }^{5}$ However, after two years, diplomatic relations were restored as well as political and economic cooperation between the two countries. Subsequently, a Joint Declaration on Deepening the Relationship of Mutual Cooperation and Benefits was signed in 2007 (China.org, 2009; The State Council of the PR China, 2007). However, the high-level visits did not occur, but the Chinese government donated 1.6 million dollars' worth school buses in 2011, and the Confucius Institute was opened at Saints Cyril and Methodius University of Skopje in which the North Macedonians have the opportunity to learn Chinese (Hanban News, 2013).

After the start of the BRI implementation, cooperation between the two countries has significantly deepened, and they have mostly been taking place within the established "17+1" Mechanism. North Macedonian exports to the Chinese market are much higher than in other countries in the region because Macedonia has high quality ferronics. There is little Chinese direct investment, most of them are projects with loans given by Chinese banks under preferential conditions. The most important project involving Chinese companies is the construction of the Kozjak hydroelectric plant in the Treska river canyon. Also, considerable Chinese funds were earmarked for the construction of the two highways - the western Kičevo-Ohrid and the eastern Miladinovci-Štip (Kraljevski, 2015). At the Summit of the prime ministers of "17+1" held in Belgrade in December 2014, the Macedonian Prime Minister Nikola Gruevski signed an agreement on building a fast railway from Budapest to Thessaloniki with Chinese Prime Minister Li Keqiang (China Military Online, 2014). In order to realize this project, the Macedonian government purchased six passenger trains

\footnotetext{
${ }^{5}$ Macedonia recognized Taiwan due to a promise to receive direct economic investment
} assistance worth 235 million dollars. 
from China Railway Rolling Stock Corporation, but the reconstruction and modernization of this railway has not yet started (Asia Times, 2016). Regarding cultural cooperation, North Macedonia is very important for China, because the seat of the Cultural Cooperation Coordination Center of "17+1" Mechanism is in Skopje.

Albania. In the period before 2013, Albania and China had good political relations. In 2001, Albania and China signed three agreements, covering the financial, mortgage and technical aspects of building the Bushat Hydropower Station in northern Albania. In 2005, cooperation between the military forces of the two countries began, which opened new opportunities in the military sector (Poulain, 2017). Four years later, in April 2009, the Albanian Prime Minister Sali Berisha visited Beijing, and then the Joint Statement on deepening traditional friendly relations was signed. There were no high-level visits by Chinese officials to Albania (Arežina, 2020b, p. 5).

After the start of the BRI implementation, there were also very few bilateral contacts between the Chinese and Albanian leaders, except within the "17+1" Mechanism. Trade between the two countries has been increasing year by year, and China is today among Albania's five largest economic partners. In addition, the two countries also cooperate in the fields of culture, education, science and technology, agriculture, sports, radio and television, as well as within international forums. But, although co-operation under the "17+1" Mechanism and BRI helps relations between the two countries to go uphill and top officials meet several times a year, progress in relations is slow and symbolic, as evidenced by the lack of visits of the Chinese President and Prime Minister to Albania, as well as a small number of investments, which so far do not exceed the value of 800 million dollars. One of the most significant is the takeover of a Canadian oil company Banker's Petroleum, which operates in Albania, including the Patos-Marinze and Kucova oil fields, by Geo-Jade Petroleum Corp (Oil\&Gas Journal, 2016). Also, the Chinese company Everbright Limited acquired the airport Mother Teresa in Tirana until 2027 through concession (Everbright, 2016). In addition, the Chinese company Sinomine Resource Exploration has established a daughter company in Albania, which is working on the construction of mines and geological tests in cooperation with the Albanian Geological Institute. In 2017, China granted a relatively modest 1.5 million euros to the Albanian government to modernize the agricultural sector, and 2 million dollars for the reconstruction of the National Theatre of Opera and Ballet and the Popular Ensemble (Qori, 2017). China also invests heavily in the Albanian agricultural sector. In 2013, the Confucius Institute was founded at the University of Tirana where the wider public can learn Chinese (Hanban News, 2014). 


\section{CONCLUSION}

The starting point of this research was to strengthen China's presence in the European Union market, which is a consequence of its accelerated economic development and the need to continue to maintain high economic growth, satisfy the needs of the internal market for vital resources and new markets for the distribution of domestic products, all with the aim of improving the standards of its citizens and keeping the Communist Party of China in power. As a result, China has begun to strengthen relations with countries that aspire to become EU member countries, and with which it has traditionally had good relations since the period of the Cold War. In this regard, at the beginning of the research the author defined the history of relations between the Western Balkan countries and China bilaterally since 1949, and multilaterally within BRI. Since 2013, BRI has become China's most significant overseas initiative, serving to meet China's strategic goals. However, due to new international circumstances (strengthening of the Sino-US rivalry and COVID-19 pandemic) in next five years the Chinese government will allocate less funds for projects within BRI.

During the research, the factors that influence the Western Balkan countries' cooperation with China were identified. Summarizing them, it was concluded that most factors have a positive impact on the Western Balkan region's relations with China, and that only a minority of them have a negative impact. Thanks to the influence of positive factors, the Sino-Western Balkans cooperation has developed significantly since 2013, which can be seen in the comparative analysis. All Western Balkan countries have signed memorandums of cooperation with China within this initiative (North Macedonia (2014), Serbia (2015), Albania (2017), Bosnia and Herzegovina (2017), and Montenegro (2017)), and some of them have become members of the Asian Infrastructure Investment Bank, an institution established in 2015 to support the initiative (Serbia in 2015). Several dozen joint projects have been completed so far, many of which are of strategic importance to the Western Balkan countries. The value of these projects has almost exceeded the funds earmarked for this purpose in the CEE Investment Fund. However, there are still many more preferential loans than investments. These loans, although obtained on preferential terms, will have to be repaid by the Western Balkan countries, which is a limiting factor for cooperation during the expected crisis caused by the COVID-19 pandemic.

Having in mind the negative factor - the reduction of Chinese investments and loans abroad, it is clear that China will continue to invest and lend only to countries with which it has extremely good political relations and which are able to repay their debts. The research concluded that China has good political relations with all Western Balkan countries which have made significant progress since 2013, especially when it 
comes to Serbia. Although they have a problem with rising public debts, some of them such as Serbia, Bosnia and Herzegovina and North Macedonia don't have problems with repaying debts to Chinese financial institutions. However, their public debts will increase as long as the crisis caused by the COVID-19 pandemic lasts, which will inevitably lead governments to prioritize spending and support for households and businesses over financing for BRI infrastructure and other projects. Montenegro and Albania have a high public debt because of tourism-dependent economy, which is likely to result in seeking refinancing loans. Also, one should keep in mind the pressure that will come from the EU regarding the Sino-Western Balkans cooperation, but it should not have much effect given the slowdown of the entire EU accession process and the need to diversify funding sources due to the COVID-19 pandemic.

Therefore, it can be concluded that the Western Balkan countries are in an ideal position to maintain good cooperation with China within the BRI. In this regard, one of the basic interests of the Western Balkan countries should be to increase exports to the Chinese market. Since these countries have poor export capacities, and individual export negotiations on products that are lacking in the Chinese market are proceeding very slowly and give barely visible results, they should impose themselves as partners in Beijing through political participation within BRI, and achieve political agreement. The Chinese government could draw up a list of products needed for the Chinese Market, where a place for the agricultural and animal products would be found. When it comes to exports, the focus could be on Western China, bearing in mind that there is already strong competition in eastern provinces from the companies from the US and Western Europe. In this regard, it is crucial that the Western Balkan countries work together to export as many products as possible to the large Chinese market. Also, Chinese leaders should show more understanding for the difficult position of the Western Balkan countries, primarily risking a slowdown in the European integration process to strengthen co-operation with China. They should show a willingness to put to the minimum limit for the entry of the Western Balkans companies and their products to the Chinese market. Therefore, it is the greatest responsibility of the leaders because they should show awareness, with their support and participation, that only together they can turn sources of power into successful smart power strategies and thus achieve the individual interests and goals. 


\section{REFERENCES}

Ačanski, U. (2013). Kina: novi igrač na evropskom terenu [China: a new player in the European field]. Biznis \& finansije. http://bif.rs/2013/12/kina-novi-igrac-naevropskom-terenu/\#sthash.xu3CfkRT.dpbs.

Ambasada NR Kine u Crnoj Gori (2016). Istorija bilateralnih odnosa NR Kine i Crne Gore [History of bilateral relations between the PR China and Montenegro]. http://me.chineseembassy.org/mon/zhgxs/t1411160.htm.

Arežina, S. (2018). China in Europe, Institute of European Studies, Belgrade, 2018.

Arežina, S. (2020a). Post-Pandemic World and Western Balkans: Transformative Resilience as the Response to the Consequences of the COVID-19 Pandemic. China-CEE Institute 41. https://china-cee.eu/wp-content/uploads/2020/11/ Working_paper-202041-Sanja-Arez\%CC\%8Cina.pdf.

Arežina, S. (2020b). Reflections of the "Belt and Road" Initiative and China-CEEC Cooperation on the Perceptions of China Pervading the Public Discourse in Albania. China-CEE Institute 27. https://china-cee.eu/wp-content/uploads/ 2020/07/Working_paper-202027-by-Sanja-Arez\%CC\%8Cina.pdf.

Ath, A. (2016). China in the Balkans: Macedonia, Albania seek Beijing's funds for projects. Asia Times. http://www.atimes.com/article/china-in-the-balkansmacedonia-albania-seek-beijings-help-in-building-infrastructure.

China.org (2001). China, Macedonia Normalize Relations. http://china.org.cn/english/ 2001/Jun/14858.htm.

China Military Online (2014). Chinese premier highlights infrastructure projects with CEE countries. http://english.chinamil.com.cn/news-channels/today-headlines/ 2014-12/18/content_6275101.htm.

COASI (2018). 20th EU-China Summit report, Beijing, 2018.

Ekapija (2009). Vlada Crne Gore kupuje dva trgovačka broda kineske proizvodnje [The Montenegrin government is buying two Chinese-made merchant ships]. http://www.ekapija.com/website/sr/page/269472/Vlada-Crne-Gore-kupujedva-trgovapercentC4percent8Dka-broda-kineske-proizvodnje.

Everbright (2016). China Everbright Limited Acquired Tirana International Airport. http://www.everbright165.com/NewsDetails/all/2016/3701?IR=false.

Ferguson, N. (2007). Not two countries, but one: Chimerica". The Telegraph. www.telegraph.co.uk/comment/personal-view/3638174/Not-two-countriesbut-one-Chimerica.html.

Gong, W. (2013). Chinese Experience of Development, Lecture, Seminar "China's issues". Beijing: Chinese Academy of Governance.

Hanban News. (2015). First Confucius Institute in Bosnia and Herzegovina officially inaugurated. http://english.hanban.org/article/2015-04/22/content_590519.htm.

Hanban News. (2014). Inauguration Ceremony of the Confucius Institute at the University of Tirana Successfully Held in Albania. http://english.hanban.org/article/201401/03/content_520538.htm.

Hanban News. (2018). Second Confucius Institute in Bosnia and Herzegovina inaugurated. http://english.hanban.org/article/2018-01/29/content_716728.htm.

Hanban News. (2013). The 1st Confucius Institute Established in Macedonia. http://english.hanban.org/article/2013-09/05/content_510806.htm.

Kavalski E. (2019). China's '16+1' Is Dead? Long Live the '17+1'. The Diplomat. https://thediplomat.com/2019/03/chinas-161-is-dead-long-live-the-171.

Kynge, J., Wheatley J. (2020). China pulls back from the world: Rethinking Xi's 'project of century'. Financial Times. https://www.ft.com/content/d9bd8059d05c-4e6f-968b-1672241ec1f6. 
Kraljevski, M. (2015). Kineski kapital u Makedoniji: skupe autoceste i kreditiranje korupcije [Chinese capital in Macedonia: expensive highways and lending to corruption]. Bilten. 10 April 2015, http://www.bilten.org/ ?p=6040.

Liu, Z. (2013). The Pragmatic Cooperation between China and CEE: Characteristics, Problems and Policy Suggestions. Working Paper Series on European Studies. Institute of European Studies and Chinese Academy of Social Sciences, 7, 6. http://ies.cass.cn/webpic/web/ies2/en/UploadFiles_8765/201311/201311151000 2690.pdf

Ministry of Commerce of the PR China. (2020). China's investment and cooperation with countries along the "Belt and Road" from January to October 2020. http://fec.mofcom.gov.cn/article/fwydyl/tjsj/202011/20201103018502.shtml.

Ministry of Foreign Affairs of the PR China (2013). China and Montenegro. http://www.fmprc.gov.cn/mfa_eng/wjb_663304/zzjg_663340/xos_664404/gjl b_664408/Montenegro_664680.

Mitrović, D. (2011). Kineska politika prema Zapadnom Balkanu - Jugoistočnoj Evropi. In: Simić, D. (Ed.): Integracija Zapadnog Balkana u mrežu globalne bezbednosti. Beograd: Čigoja.

Mondo (2017). Kineski kulturni centar - 'najlepša zgrada' [China's Cultural Center the most beautiful building'], 20 July 2017.

Oil\&Gas Journal (2016). Geo-Jade acquiring Bankers Petroleum. http://www.ogj.com/ articles/2016/03/geo-jade-acquiring-bankers-petroleum. html.

Pavlićević, D. (2019). Structural power and the China-EU-Western Balkans triangular relations. Asia Europe Journal 17 (4). https://link.springer.com/article/ 10.1007\%2Fs10308-019-00566-y.

Poulain, L. (2011). China's new Balkans Strategy. Central Europe Watch 1 (2). http://csis.org/files/publication/110829_CEW_China_in_Balkans.pdf.

Quori, A. (2017). Albania and China: the reemergence of and old friendship. https://www.criticatac.ro/lefteast/albania-and-china-the-reemergence-of-anold-friendship/.

Rhodium Group (2019). Chinese FDI in Europe: 2019 Update. https://rhg.com/ research/chinese-fdi-in-europe-2019-update/

Smith, J. (2018). China's Belt and Road Initiative: Strategic Implications and International Opposition. The Heritage Foundation. https://www.heritage.org/ asia/report/chinas-belt-and-road-initiative-strategic-implications-andinternational-opposition.

Song, T. (2012). Kineska pomoć Evropi [China's assistance to Europe]. Politika. http:// www.politika.rs/rubrike/Svet/Kineska-pomoc-Evropi.lt.html.

The State Council of the PR China (2007). Joint statement between China and Macedonia. http://www.gov.cn/misc/2007-12/05/ content_826315.htm.

Thilo Hanemann et al. (2019). Chinese FDI in Europe: 2018 trends and impact of new policies. Papers on China. Merics. https://www.merics.org/en/papers-onchina/chinese-fdi-in-europe-2018.

United States Senate (2018). Senators' Letter to Michael Pompeo and Steven Mnuchin. https://www.perdue.senate.gov/imo/media/doc/IMF\%20China\%20Belt\%20an d\%20Road\%20Initiative\%20Letter.pdf.

US Embassy in Georgia (2017). National Security Strategy of the United States of America. https://ge.usembassy.gov/2017-national-security-strategy-unitedstates-america-president.

Vukićević, J. (2020). Zašto se Crnoj Gori predviđa najveći rast javnog duga na Zapadnom Balkanu? [Why Montenegro predicts the largest increase in public debt in the Western Balkans?]. Radio Slobodna Evropa. https://www.slobodnaevropa.org/ 
a/za\%C5\%A1to-se-crnoj-gori-predvi\%C4\%91a-najve\%C4\%87i-rast-javnogduga-na-zapadnom-balkanu-/30894955.html.

Wen, J. (2011). Strengthen Traditional Friendship and Promote Common Development. Budapest: The China-CEE Economic Forum.

Winfield, N. (1999). China Vetoes, Global Policy Forum, https://www.globalpolicy. org/component/content/article/190/33325.html.

World Bank (2020). Western Balkans Regular Economic Report: Fall 2020. https://www.worldbank.org/en/region/eca/publication/western-balkansregular-economic-report.

Xinhua (2013). Zhonggong zhongyang guanyu quanmian shenhua gaige ruogan zhongda wenti de jueding (quanwen) [Central Committee's Decision on Major Issues Concerning Comprehensively Deepening Reforms (full text)]. Chapter 7. Point 26.

\title{
ОДНОСИ КИНЕ И ЗАПАДНОГ БАЛКАНА У ОКВИРУ МЕХАНИЗМА ,ПОЈАС И ПУТ" ИНИЦИЈАТИВЕ УСРЕД СВЕТСКЕ БОРБЕ СА РАСТОМ КИНЕ
}

\author{
Сања Арежина \\ Влада Републике Србије, Београд, Република Србија
}

Резиме

Невероватан економски развој Кине у последњих неколико деценија омогућио је овој земљи да постане прва трговинска сила и друга економија у свету (по номиналном БДП-у). Ипак, на европско тржиште Кина је успела да продре тек након Велике рецесије и кризе Еврозоне, првенствено захваљујући потреби европских држава за свежим капиталом, те се може рећи да је данас на европском тржишту присутна као трговински партнер, инвеститор и извор кредитирања. У складу са тим, крајем прве деценије 21. века почиње да јача сарадња између Кине и Западног Балкана. Односи су развијани на билатералном и мултилатералном нивоу, у оквиру „Један појас, један пут” иницијативе (иницијатива „Појас и пут” - БРИ), која је промовисана 2013. године и која је обухватила претходноосновани Механизам сарадње Кине и земаља Централне и Источне Европе (Механизам „17+1”). Иако је кинески председник Си Ђинпинг 2017. године БРИ назвао „пројектом века”, нове међународне околности изазване појачаним ривалством између САД и Кине и пандемијом вируса корона SARS-CoV-2 учиниле су да кинеско руководство на састанку Политбироа у мају 2020. године преиспита активности и финансирања у иностранству и нови, 14 . по реду, Петогодишњи план усклади са променама које су се десиле у претходних пет година. У том смислу, одлучено је да у наредном периоду Кина фокус стави на двоструку циркулацију, која треба да омогући коришћење свих предности глобализације уз истовремено коришћење сопствених капацитета. То значи да ће Кина смањити број активности и инвестиција (и зајмова) у оквиру БРИ и средства преусмерити на инвестирање у домаће капацитете. Ауторка у чланку разматра односе Кине и Западног Балкана од 1949. године до 2013. године, када је започела примена БРИ, факторе који утичу на сарадњу Кине са државама Западног Балкана и анализира напредак сарадње након почетка примене БРИ у односу на претходни период. Да би доказала основну хипотезу да ће се сарадња између Кине и Западног Балкана у окви- 
ру иницијативе „Појас и пут” и даље развијати у позитивном смеру, упркос утицају негативних фактора, а пре свега због добрих резултата постигнутих у оквиру иницијативе „Појас и пут” 2013. године, ауторка користи структурно-функционалну анализу, компаративну анализу, индукцију и дедукцију. 